\title{
Finding a Potential Bruceine D Inhibitor for Apoptotic Resistance Protein Pancreatic Cancer Based on Molecular Docking
}

\author{
Armi Wulanawati ${ }^{1, *}$, Harry Noviardi ${ }^{2}$, and Muhamad Sholehuddin Malik Ibrohim ${ }^{1}$ \\ ${ }^{1}$ Department of Chemistry, Faculty of Mathematics and Natural Sciences, Bogor Agricultural University, \\ Tanjung Street, IPB Campus Dramaga, Bogor 16680, Indonesia \\ ${ }^{2}$ Department of Pharmacy, Sekolah Tinggi Teknologi Industri dan Farmasi Bogor, \\ Jl. Kumbang No. 23, Bogor 16151, Indonesia
}

Received May 23, 2017; Accepted March 3, 2018

\begin{abstract}
Pancreatic cancer arises when cells in the pancreas begin to multiply out of control. In pancreatic cancer, over expression of heat proteins (Hsp70, Hsp 90), constitutive activation of $\mathrm{NFKB}$, and Bcl-2 family are closely linked with resistance to apoptosis. Apoptotic resistance has been attributed to defects in apoptotic signaling pathways. Bruceine $D$, which found in abundance Brucea javanica, possesses potent anti-pancreatic cancer activity. In vitro result, bruceine $D$ could induce apoptosis of pancreatic cancer cell. The aim of this study was to find the potential effect of bruceine $D$ inhibitor on apoptotic resistance proteins in pancreatic cancer based on molecular docking. Docking showed a binding affinity between bruceine $D$ with proteins involved in apoptosis using AutoDock. The results showed that free binding energy of Hsp70 is -5.19; Hsp90 -7.26; NFKB1 -5.49; NFKB2 -6.14; Bcl-W -6.02; $B c \mathrm{l}-x \mathrm{~L}-5.45 \mathrm{kcal} / \mathrm{mol}$. Based on the result, we conclude that bruceine $D$ with $\mathrm{Hsp} 90$ protein has potential the best binding affinity than other proteins.
\end{abstract}

Keywords: apoptotic resistance; bruceine D; inhibitor; pancreatic cancer; protein

\section{ABSTRAK}

Kanker pankreas disebabkan oleh pertumbuhan sel yang berlebih dan tidak dapat dikendalikan oleh proses apoptosis sel. Apoptotic resistance sel disebabkan oleh adanya ekspresi berlebih dari protein heat (Hsp70, Hsp 90), $N F K B$, dan Bcl-2. Ekspresi berlebih dari protein-protein tersebut dapat menghambat mekanisme kematian sel kanker. Brusein $D$ merupakan senyawa aktif dari tanaman Brucea javanica yang memiliki potensi sebagai anti kanker prostat. Penelitian secara in vitro menunjukkan senyawa brusein $D$ dapat meningkatkan apoptosis sel kanker. Penelitian bertujuan menentukan inhibisi senyawa brusein $D$ terhadap protein-protein yang berperan dalam apoptotic resistance dengan metode molecular docking. Docking dilakukan dengan menggunakan AutoDock untuk menentukan afinitas ikatan serta energi bebas ikatan antara brusein $D$ dan protein target. Hasil penelitian menunjukan energi bebas ikatan brusein D dan protein Hsp70 adalah -5.19; Hsp90 -7.26; NFkB1 -5.49; NFkB2 -6.14; Bcl-W -6.02; Bcl-xL -5.45 kkal/mol. Potensi inhibisi senyawa brusein D dengan protein Hsp90 memiliki nilai afinitas ikatan terbesar dibandingkan dengan protein yang lain.

Kata Kunci: apoptotic resistance; brusein D; inhibitor; kanker pankreas; protein

\section{INTRODUCTION}

Pancreatic cancer is an uncommon tumor, but because the mortality rate approaches $100 \%$, this form of cancer has now become a common cause of cancer mortality [1]. The poor prognosis of pancreatic cancer has been attributed to its late diagnosis, aggressive local invasion, and early metastases [2]. This cancer has a poor prognosis with a 5 year survival rate of less than 5 . Apoptotic resistance made the chemotherapy and radiotherapy could be not responding to this cancer. It has been attributed to defects in apoptotic signaling pathways. In pancreatic cancer, over expression of heat proteins (Hsp70, Hsp90), constitutive activation of $\mathrm{NFKB}$, and Bcl-2 family are closely linked with resistance to apoptosis [3].

The standard chemotherapy approach for pancreatic cancer is treatment which the pyrimidine analog gemcitabine [4]. However, the efficacy of chemotherapy in these patients is generally poor because of the cancer cells low sensitivity [5]. The apoptotic resistance of this cancer is most often the culprit for therapy failures [6]. Therefore, this is an

${ }^{*}$ Corresponding author.

DOI: $10.22146 /$ ijc. 25220

Email address : armiwulanawati@yahoo.com

Armi Wulanawati et al. 
urgent need to explore the molecular mechanisms and develop new effective treatments for pancreatic cancer.

The compounds were selected for evaluation as potential anticancer agents could be of natural or synthetic origin. Compounds from natural product have often provided new leads in the novelty of structures with anticancer activity. It was also necessary to investigate the activity of binding affinity and toxicity of these components. Brucea javanica fruitspossess potent antipancreatic cancer activity. Bruceine $D$ is a quassinoid found abundantly in $B$. javanica fruit. It has functioned as anti-proliferative and apoptogenic actions. Bruceine D inhibited the growth of three pancreatic cancer cell lines [7].

Drug design process is very costly and a long time. Therefore, the molecular docking method is the first step in structure-based drug design. This method is very fast, cost-effective and accurate. Screening of drug candidates for anticancer activity was done in several stages, which were designed to reduce the number of compounds entering development stages. The recent development at a molecular level had improved with target-based drugs. These pre-designed drugs inhibit a selected molecular marker that was important in cancer prognosis, growth, and metastasis.

Drug design could be performed in silico to determine the three-dimensional structure of the active and the target enzyme. Though the docking process may predict molecules which act as inhibitors so that the process of screening and testing experimentally to be efficient. In this study conducted in silico using molecular docking method included in molecular modeling. By molecular modeling designed and displayed structure and properties of certain molecules using techniques of computational chemistry and graphical visualization [8].The aim of this study was to find the potential effect of bruceine $D$ inhibitor on apoptotic resistance proteins in pancreatic cancer based on molecular docking.

\section{EXPERIMENTAL METHOD}

The instruments of hardware and software were used in this work. The hardware specifications were a computer equipped with chip processor AMD A10-6800K quadcore $4.1 \mathrm{GHz}$, random access memory (RAM) $8 \mathrm{~GB}$, and video graphics array AMD Radeon HD 8670D.

Software used in this study included AutoDockTools 1.5.6 rc1 with AutoDock4.2 (The Scripps Research Institute, USA), and PyMol 1.7 (DeLano Scientific LLC, Italy), Discovery Studio Visualizer, Vega 1.2.4.

The crystal structure of apoptotic resistance protein from the database Protein Data Bank (http://www.rscb.org/pdb/). The PDB codes were used $4 \mathrm{IO}$ (Hsp70), 4CWF (Hsp90), 2DBF (NFkB 1 ), 2D96
(NFKB 2$), 1 Z Y 3(B c l-W)$ and 3ZK6 (Bcl-XI), brucein D and gemcitabine (Fig. 1) were downloaded PubChem (http://pubchem.ncbi.nlm.nih.gov/). The properties of the ligands were computed by using Molinspiration (http://www.molinspiration.com/) and Vega 1.2.4.

\section{Molecular Docking Simulation}

Docking process was carried out using protein and 1 active compounds. The 3D protein structure also needs to be generated for docking. Docking files were prepared by using AutoDockTools 1.5.6. Docking was carried out to investigate inhibition protein activity by analyzing the binding affinity using AutoDock 4.2 program. The size of the docking grid was optimized, which encompassed the entire protein binding site.

The 3-dimensional structures were visualized with AutodockTools. Input is entered in the format .pdb GDP data, then converted in the format .pdbqt. Protein surface visualized by using AutodockTools Autogrid to see the value of the bond and the catalytic side.

Preparation of files docking performed geometry optimization and energy $\Delta G_{\text {bind }}$ of 3-dimensional structures of ligands by using AutoDockTools 1.5.6 entering the parameter value of the bond and the catalytic side. Docking simulation runs with 100 runs using
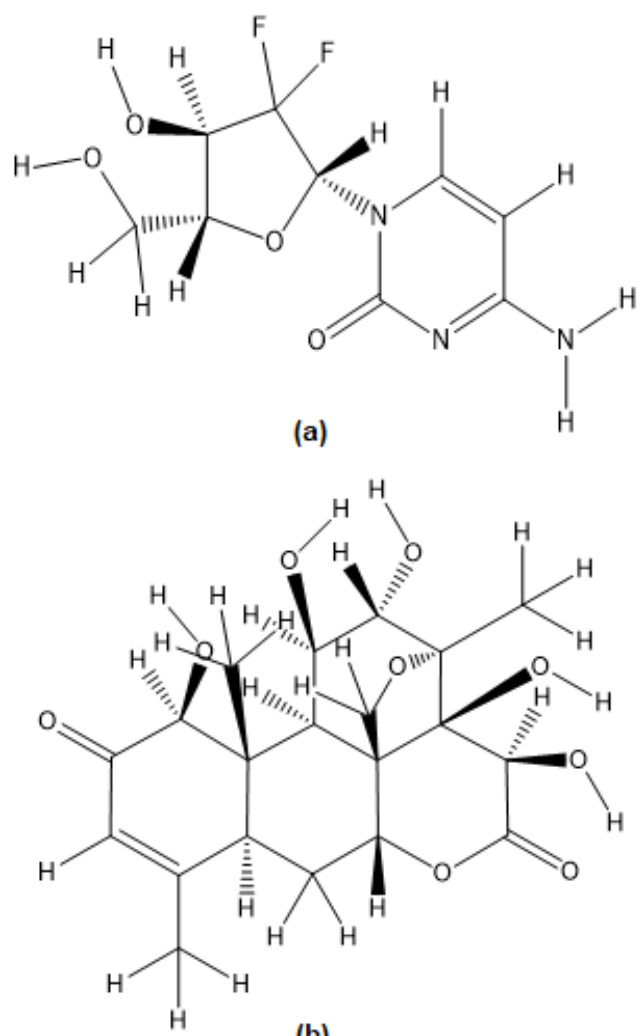

(b)

Fig 1. 2D structure of (a) gemcitabine and (b) bruceine $\mathrm{D}$ 
Lamarckian Genetic Algorithm. The free energy $(\Delta G)$ and inhibitions constant (Ki) scoring were then calculated [9]. After the docking simulation, we visualized the result with PyMol [10] and Discovery Studio Visualizer.

\section{RESULT AND DISCUSSION}

Protein docking is a method that predicts the bound conformation of one protein to another protein or a ligand. Autodock is a protein docking program in virtual screening of structure based drug design. AutoDock uses three different conformation search algorithms, simulated annealing (SA), traditional genetic algorithm (GA), and Lamarckian genetic algorithm (LGA). The all algorithm is implemented in AutoDock to find the optimal conformation with the lowest binding energy [11]. In this work used Lamarckian genetic algorithm (LGA). The Lamarckian genetic algorithm is the best search algorithm used in AutoDock so far [12].

AutoDockTools was used to prepare, run and analyze the docking simulation using bruceine $D$ and apoptotic resistance protein (Hsp70, Hsp90, NFkB ${ }_{1}$, $\left.\mathrm{NFKB}_{2}, \mathrm{Bcl}-\mathrm{W}, \mathrm{Bcl}-\mathrm{XI}\right)$. The target protein was kept as rigid and the bruceine $D$ being docked was kept flexible, in order to explore an arbitrary number of torsional degrees of freedom in addition to the six spatial degrees of freedom spanned by the translational and rotational parameters [13]. The hybrid approach with rigid receptors will be preferred due to their accuracy and computational efficiency [14].
Protein structure does not have any water molecules. It should make the protein is free receptor. Then, Polar hydrogens were added into the protein file for the preparation of protein in docking simulation. Since, bruceine D is not peptides, Gasteiger charge was assigned and then non-polar hydrogens were merged [13].

AutoDockTools requires pre-calculated grid maps, one for each atom type present in the flexible molecules being docked and its stores with the potential energy arising from the interaction with rigid macromolecules [15]. This grid must surround the active site region of interest in the rigid macromolecule [16]. Table 1 showed that grid of the docking simulation. Each apoptotic resistance protein has a different grid, based on active site position in structure molecule. Docking simulations carried out on the active protein receptor

Table 2 showed the calculated free binding energy $(\Delta G)$ and inhibition constants (Ki) of flexibleligand docking simulation. The negative and low value of $\Delta G$ indicated the strong favorable bond between enzyme and ligand. From the docking simulation, we retrieved the strongest bruceine $\mathrm{D}$ ligand-protein interaction from bruceine $\mathrm{D}$ to Hsp90, which has a higher binding affinity as much as $-7.26 \mathrm{kcal} / \mathrm{mol}$. There is a relationship between the values of the $\Delta G$ with inhibition constants (Ki) [17]. The increase in the negative value of $\Delta G$ indicates enzyme-ligand complexes bind will be much stronger. This is due to the stability and strength of non-covalent interactions in

Table 1. The grid box of docking simulation

\begin{tabular}{lcccccc}
\hline \multirow{2}{*}{ Protein } & \multicolumn{3}{c}{ Grid $(\dot{\mathbf{A}})$} & \multicolumn{3}{c}{ Grid Size (文) } \\
\cline { 2 - 7 } & $\mathbf{x}$ & $\mathbf{y}$ & $\mathbf{Z}$ & $\mathbf{x}$ & $\mathbf{y}$ & $\mathbf{Z}$ \\
\hline Hsp70 & 0.551 & 0.347 & 16.106 & 40 & 44 & 40 \\
Hsp90 & 0.261 & 15.030 & 24.191 & 54 & 46 & 44 \\
NFkB1 & 5.048 & 4.968 & 1.404 & 50 & 44 & 52 \\
NFkB2 & 9.334 & -9.326 & -11.197 & 46 & 46 & 46 \\
Bcl-w & -7.470 & -4.004 & -6.589 & 48 & 52 & 40 \\
Bcl-xL & 20.590 & 52.548 & 0.136 & 50 & 50 & 60 \\
\hline
\end{tabular}

Table 2. Type of protein, predicted ligand, free binding energy and hydrogen bond in docking simulation

\begin{tabular}{|c|c|c|c|c|c|}
\hline Ligand & Protein & PDB ID & $\begin{array}{c}\text { Predicted } \Delta \mathbf{G} \\
(\mathrm{kcal} / \mathrm{mol})\end{array}$ & $\begin{array}{c}\text { K inhibition } \\
(\mathrm{mM})\end{array}$ & $\Sigma$ Hydrogen Bond \\
\hline \multirow{6}{*}{ Gemcitabine } & Hsp70 & 4108 & -5.19 & 156.10 & 6 \\
\hline & Hsp90 & 4CWF & -7.26 & 4.73 & 4 \\
\hline & NFKB1 & 2DBF & -5.49 & 94.05 & 5 \\
\hline & NFkB2 & $2 \mathrm{D} 96$ & -6.14 & 31.38 & 6 \\
\hline & $\mathrm{Bcl}-\mathrm{W}$ & $1 Z Y 3$ & -6.02 & 38.43 & 2 \\
\hline & $\mathrm{Bcl}-\mathrm{XI}$ & $3 Z \mathrm{~K} 6$ & -5.45 & 100.62 & 1 \\
\hline \multirow{6}{*}{ Bruceine D } & Hsp70 & 4108 & -3.93 & 132.00 & 4 \\
\hline & Hsp90 & 4CWF & -5.97 & 42.05 & 4 \\
\hline & NFkB1 & 2DBF & -3.75 & 178.00 & 5 \\
\hline & NFKB2 & $2 \mathrm{D} 96$ & -5.33 & 124.70 & 5 \\
\hline & $\mathrm{Bcl}-\mathrm{W}$ & $1 Z Y 3$ & -5.30 & 130.24 & 2 \\
\hline & $\mathrm{Bcl}-\mathrm{XI}$ & $3 Z \mathrm{~K} 6$ & -5.44 & 102.19 & 2 \\
\hline
\end{tabular}




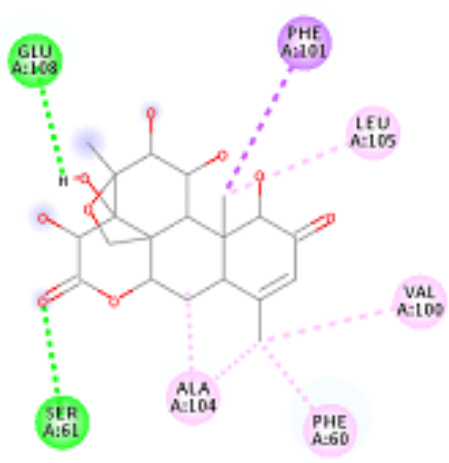

(a)

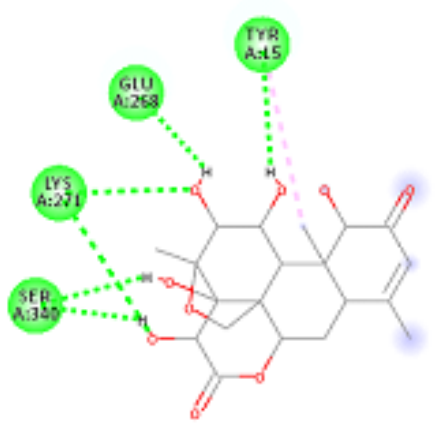

(c)

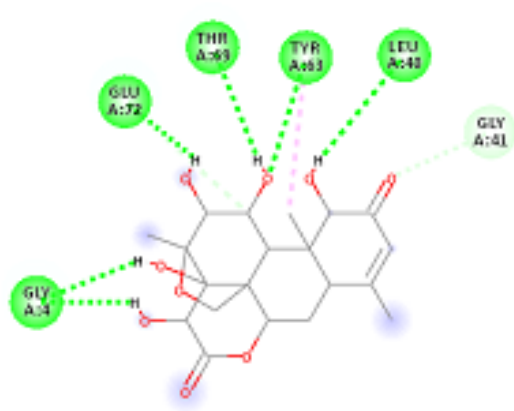

(e)

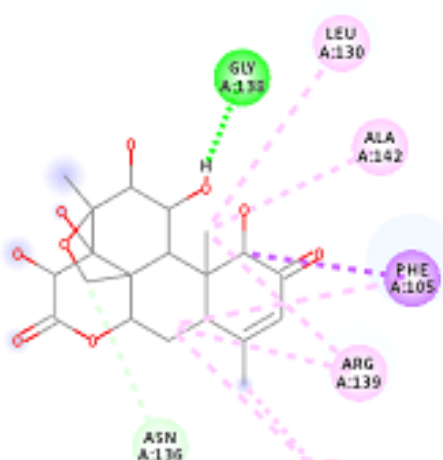

(b)

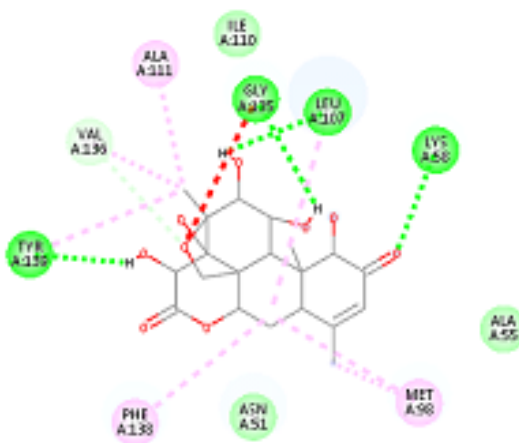

(d) TMR

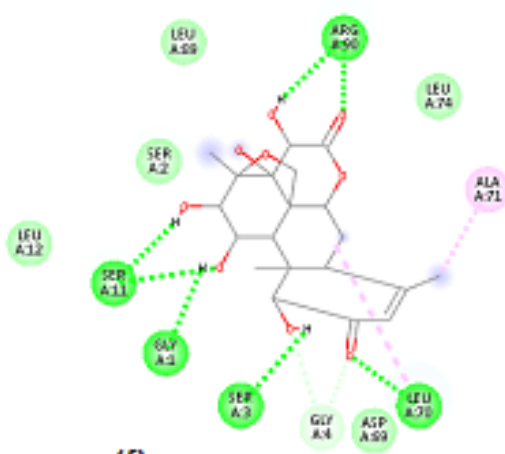

(f)

SF

Interactions

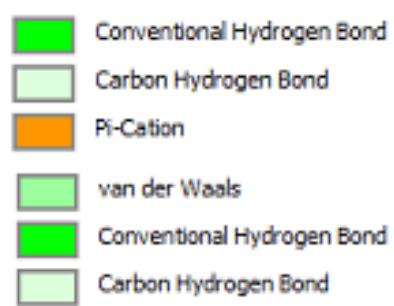

Amide.Pistacked

PirAlky

Unfavorable Acceptor-Acceptor

Alkyl

Pi-Alkyl

Fig 2. 2D-Interaction bruceine D with (a) bcl-w, (b) bcl-xL, (c) Hsp70, (d) Hsp90, (e) NFkB1, and (f) NFkB2

the enzyme-ligand complex that can be seen from the amount of free energy released during the interaction of the enzyme-ligand complex was formed [18].
After the simulations were complete, the docked structures were analyzed and the interactions were seen. Hydrogen bond interactions and the binding 

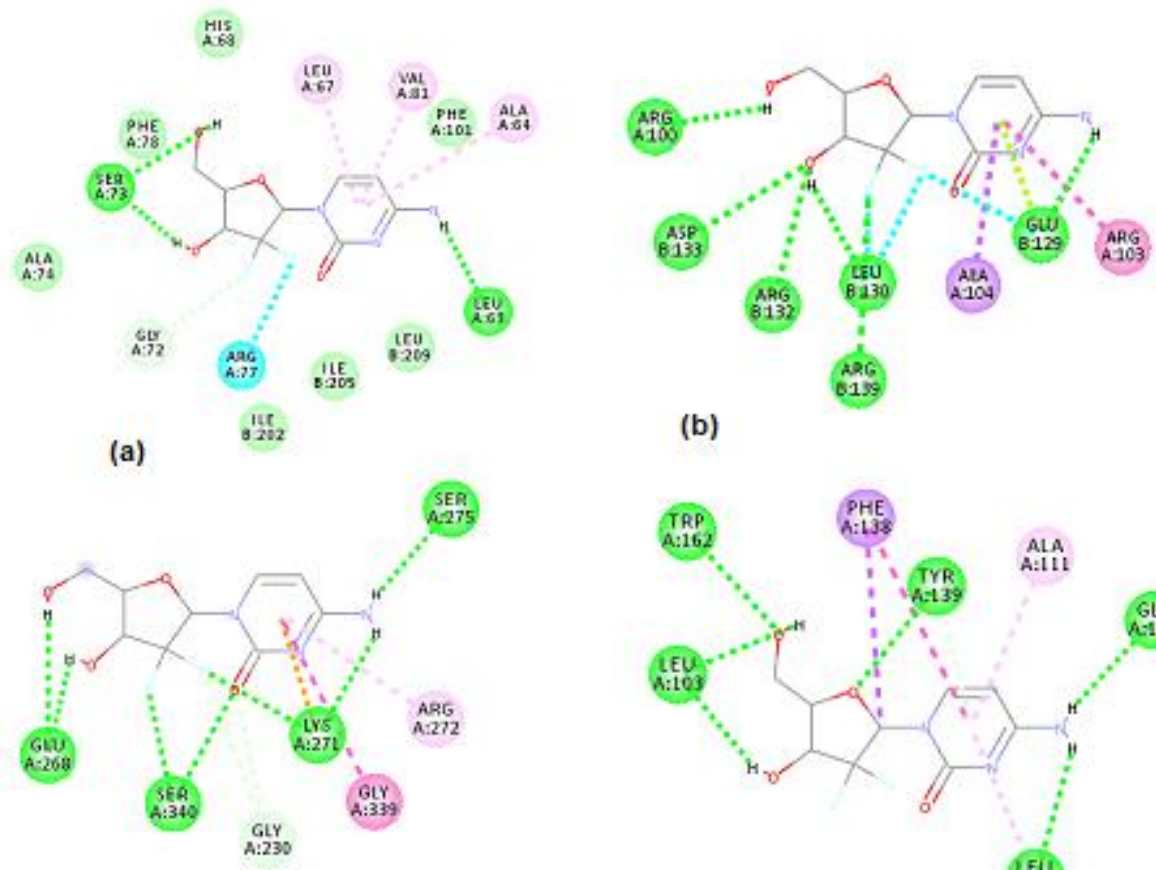

(c)
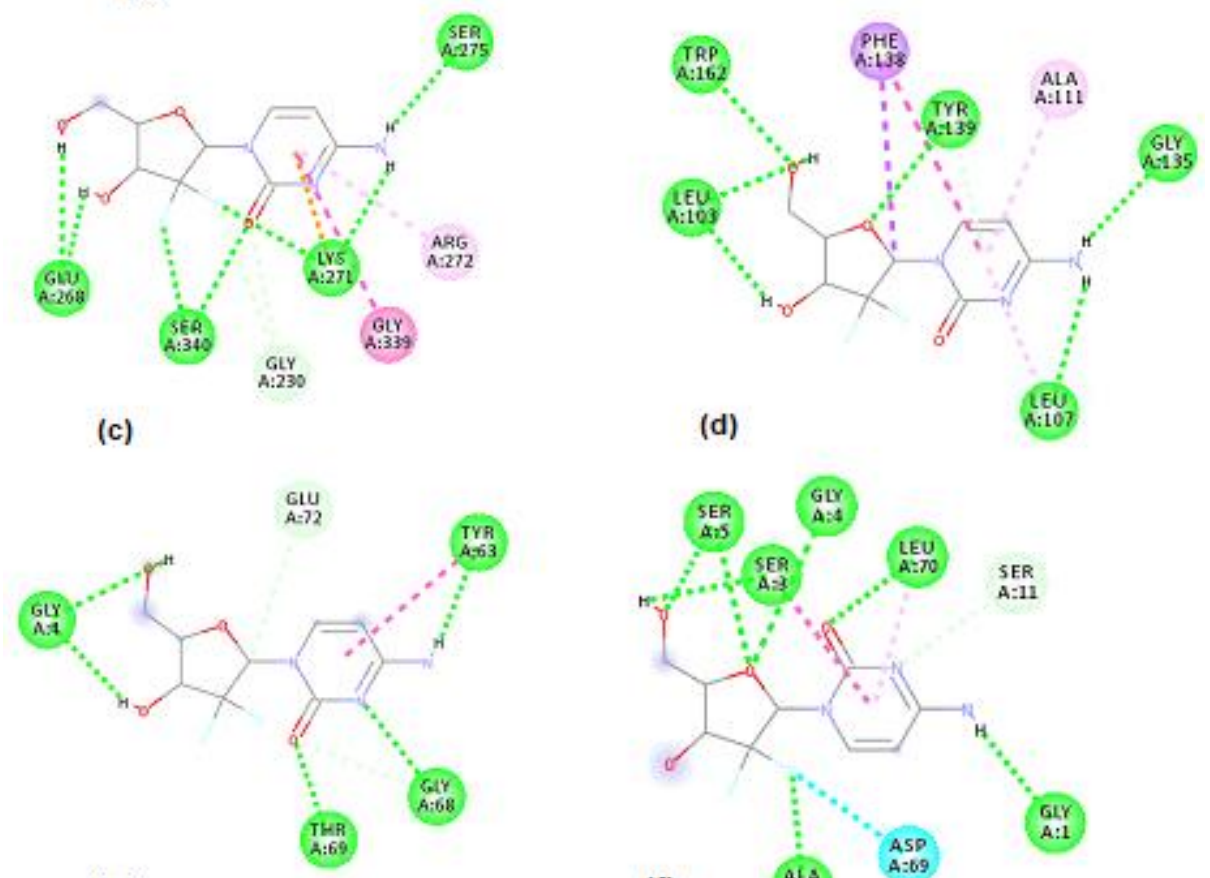

(e)
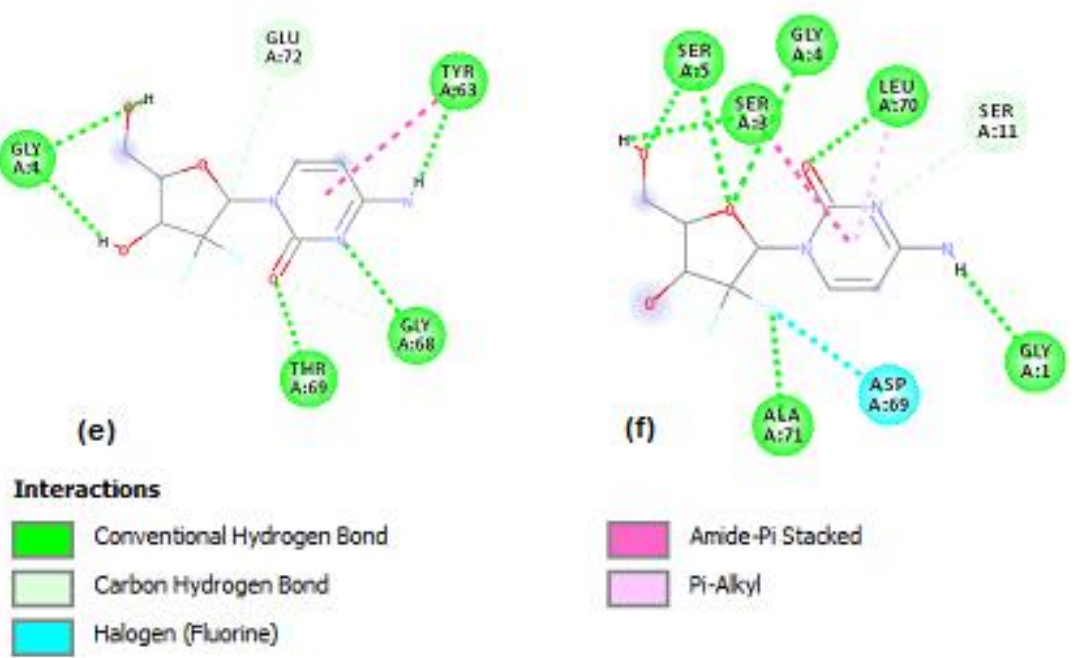

Fig 3. 2D-Interaction gemcitabine with (a) bcl-w, (b) bcl-xL, (c) Hsp70, (d) Hsp90, (e) NFkB1, and (f) NFkB2

distance between the donors and acceptors were calculated for the best conformers. Visualized docking simulation for each protein with the ligand (bruceine $D$ and gemcitabine) are shown in Fig. 2 and 3. The hydrogen bond is defined as intermolecular or intramolecular force that occurs between atoms with high electronegativity with hydrogen atoms covalently bonded to an electronegative atom.

Non-covalent interactions or non-bonding that occurs between the enzyme and the ligand can increase the affinity of the ligand to the enzyme. Non-bonding interactions represent a flexible interaction between pairs of atoms and particles. Two types of non-bonding interactions that can lead to the most common change in potential energy is the electrostatic interaction and van der Waals interactions [19]. It is necessary to analyze the complex enzyme-contact residues ligand docking simulation results can be known enzyme residues that interact with ligands. The interaction between the ligand and the enzyme is expected to disrupt the stability and performance of the enzyme [20].

In Table 3, presented properties of gemcitabine and bruceine $\mathrm{D}$ ligand compound. The descriptor analysis helped in the identification of the better drug candidates. Based on the descriptor analysis and docking 
Table 3. Ligand descriptors value

\begin{tabular}{|c|c|c|}
\hline Descriptors & Gemcitabine & Bruceine D \\
\hline $\log P$ & -1.60 & -1.33 \\
\hline TPSA & 110.61 & 153.75 \\
\hline Molecular Weight & 18 & 29 \\
\hline N Atoms & 263.20 & 410.42 \\
\hline n ON & 7 & 9 \\
\hline $\mathrm{NOHNH}$ & 4 & 5 \\
\hline N Violations & 0 & 0 \\
\hline N Rotatable bonds & 2 & 0 \\
\hline Volume & 203.36 & 348.96 \\
\hline \multicolumn{3}{|l|}{ Drug-likeness } \\
\hline GPCR ligand & 0.58 & 0.27 \\
\hline Ion channel modulator & 0.11 & 0.23 \\
\hline Kinase inhibitor & 0.33 & -0.36 \\
\hline Nuclear receptor & -1.00 & 1.00 \\
\hline Mutagenic* & Mutagen & Non-mutagen \\
\hline Carcinogenicity* & Negative & Negative \\
\hline Toxicity $\left(\mathrm{LC}_{50}\right)(\mathrm{mg} / \mathrm{L})^{*}$ & 7.7 & 77.3 \\
\hline
\end{tabular}

simulation, the bruceine D ligand could become candidate drug.

\section{CONCLUSION}

We predict that interaction between bruceine $D$ and Hsp90 is a high potential inhibitor to apoptotic resistance protein in pancreatic cancer treatment based on docking simulation. The strongest brucein $D$ ligand-protein interaction from brucein D to Hsp90, which has a higher binding affinity as much as $-7.26 \mathrm{kcal} / \mathrm{mol}$.

\section{REFERENCES}

[1] Al-Majed, H.T, El-Basmi, A.A., Al-Mohannadi, S.H., Govindan, R., and Rajakumari, G.B., 2013, Pancreatic cancer: Incidence, clinical profile, and frequency of associated factors in Kuwait, Alexandria J. Med., 49 (1), 75-80.

[2] Li, J., Wientjes, M.G., and Au, J.L.S., 2010, Pancreatic cancer: pathobiology, treatment options, and drug delivery, AAPS J., 12 (2), 223-232.

[3] Lin, L., and Leung, P.S., 2014, Use herbal medicines and natural product: an alternative approach to overcoming the apoptotic resistance of pancreatic cancer, Int. J. Biochem. Cell Biol., 53, 224-236.

[4] Strimpakos, A.S., Syrigos, K.N., and Saif, M.W., 2010, The molecular targets for the diagnosis and treatment of pancreatic cancer, Gut Liver, 4 (4), 433-449.

[5] Xia, Y., Rocchi, P., lovanna, J.L., and Peng, L., 2012, Targeting heat shock response pathways to treat pancreatic cancer, Drug Discovery Today,. 17 (1-2), 35-43.
[6] Long, J., Zhang, Y., Yu, X., Yang, J., LeBrun, D.G., Chen, C., Yao, Q., and Li, M., 2011, Overcoming drug resistance in pancreatic cancer, Expert Opin. Ther. Targets, 15 (7), 817-828.

[7] Lau, S.T., Lin, Z.X., Liao, Y., Zhao, M., Cheng, C.H., and Leung, P.S., 2009, Brucein D induces apoptosis in pancreatic adenocarcinoma cell line PANC-1 through the activation of p38-mitogen activated protein kinase, Cancer Lett., 281 (1), 4252.

[8] Leach, A.R., 2001, Molecular Modelling: Principles and Applications, Prentice Hall, New Jersey.

[9] Lestari, W., Dewi, R.T., Kardono, L.B.S., and Yanuar, A., 2017, Docking sulochrin and its derivative as a-glucosidase inhibitors of Saccharomyces cerevisiae, Indones. J. Chem., 17 (1), 144-150.

[10] The PyMOL Molecular Graphics System, Version 1.3.0.0, Schrödinger, LLC., and AutoDock programs.

[11] Atilgan, E., and $\mathrm{Hu}, \mathrm{J} ., 2011$, Improving protein docking using sustainable genetic algorithms, IJCISIM, 3, 248-255.

[12] Morris, G.M., Goodsell, D.S., Halliday, R.S., Huey, R., Hart, W.E., Belew, R.K., and Olson, A.J., 1998, Automated docking using a Lamarckian genetic algorithm and an empirical binding free energy function, J. Comput. Chem., 19 (14), 1639-1662.

[13] Gowthaman, U., JayaKanthan, M., and Sundar, D., 2008, Molecular docking studies of dithionitrobenzoic acid and its related compounds to protein disulfide isomerase: Computational screening of inhibitors to HIV-1 entry, BMC Bioinf., 9 (Suppl. 12), S14. 
[14] Elokely, K.M, and Doerksen, R.J, 2013, Docking challenge: Protein sampling and molecular docking performance, J. Chem. Inf. Model., 53 (8), 19341945.

[15] Prabahar, A., Swaminathan, S., Loganathan, A., and Jegadeesan, R., 2015, Identification of novel inhibitors for tobacco Mosaic virus infection in Solanaceae plants, Adv. Bioinformatics, 2015, 198214.

[16] Vijesh, A.M., Isloor, A.M., Telkar, S., Arulmoli, T., and Fun, H.K., 2013, Molecular docking studies of some new imidazole derivatives for antimicrobial properties, Arabian J. Chem., 6 (2), 197-204.

[17] Paramita, R.I, Arsianti, A., and Radji, M., 2017, In silico docking studies of alkyl esters derivative of gallic acid on $\mathrm{Bcl}-\mathrm{xL}$ anti-apoptotic protein of breast cancer, Int. J. ChemTech Res., 10 (1), 348-355.
[18] Tambunan, U.S.F., and Alamudi, S., 2010, Designing cyclic peptide inhibitor of dengue virus NS3-NSNS2B protease by using molecular docking approach, Bioinformation, 5(6), 250-254.

[19] Tambunan, U.S.F., Nasution, M.A.F., Parikesit, A.A., Noviardi, H., and Kerami, D., 2016, Designing of disulfide cyclic peptide for inhibiting polymerase $A$ and $B 1$ (PA C-PB1 N) in H1N1 virus using molecular simulation approach, Online $J$. Biol. Sci., 16 (3), 122-129.

[20] Du, X., Li, Y, Xia, Y.L., Ai, S.M., Liang, J., Sang, P., Ji, X.A, and Liu S.Q, 2016, Insights into protein-ligand interactions: mechanisms, models, and methods, Int. J. Mol. Sci., 17 (2), 144. 